\title{
Culture Shift in Development of Science and Technology and Efforts to Create A Low Carbon Community in Indonesia (Study Implementation of Pancasila)
}

\author{
Iriyanto Widisuseno ${ }^{1}$ \\ ${ }^{1}$ Department of Linguistics, Faculty of Humanity, Diponegoro University, Semarang - Indonesia
}

\begin{abstract}
This study aims to map the problem of shifting the culture of the Indonesian people and building a cultural strategy to overcome these problems as a step to foster awareness of low carbon communities. The initial idea of a low carbon community was to reduce carbon dioxide emissions without disrupting the continuity of the needs of the people who were supposed to live. This research uses literature study, and the theory used is social phenomenology. Through cultural phenomenological exploration can identify the problem of shifting the culture of society. Then with qualitative description analysis, it can conceptualize a map of cultural problems that can be used as a guide to conceptualizing a low-carbon society culture. The results of the study show that the development of science and technology has an impact on changes in mindset, attitudes and behavior of people who tend to be practical, pragmatic and rational. This problem has implications for changes in people's attitudes that tend to weaken the commitment or appreciation of conventional basic values in the life of the nation that upholds the values of togetherness, mutual cooperation, harmony of life.
\end{abstract}

Keywords: cultural shift; cultural approach; philosophical insight development; harmony; low carbon society.

\section{Introduction}

The cultural approach becomes very important when in the development of science and technology requires changes in behavior of people who care about low carbon. Indonesian society is currently experiencing a cultural shift as the influence of the development of modern science and technology, from conventional life patterns to modern patterns of life. Impact of development modern science and technology tend to create a system of life values that are pracctically oriented and pragmatic. The development of science and technology is currently running fast, mastering various fields of human life, such as economics, social, culture, education, information and communication [1].

Technology in the field of information and communication has been able to create an accurate, well-targeted and massive information and communication system capable of penetrating the boundaries of each region. Modern technology has led to a shift in the culture of society, namely from the habit of ways of thinking and behaving that are based on a value system of life that was once considered noble, while some people turn to the world of western life, which is practical, pragmatic and empirical. As an implication, the patterns of life of a hedonistic, materialist and consumptive society are increasingly symptomatic in the community. Disorientation and distortion occurs in the community, a cultural shift that leads the Indonesian nation to lose its identity [2]. When the nation faces fundamental problems in culture, philosophy plays an important role in resolving it through the peculiarities of approaches, namely essential, holistic and normative. The discussion of the problem is detailed into the sub-subject matter as follows; (a) The initial idea underlying the development of science and technology (b) The phenomenon of issues of cultural shift in the development of science and technology in Indonesia, (c) Philosophical strategies in addressing the problem of cultural shifts can foster a low cultural awareness

*Corresponding author: widisusenoiriyanto@yahoo.com 


\section{Method}

The method used in discussing problems; a posteriori qualitative descriptions, and philosophical heuristics. Qualitative description method aposteriori, which is an essential explorative way of thinking through a combination of logical and empirical methods, to reveal the meaning and intrinsic meaning of the development of science and technology and the phenomenon of cultural shift in the development of science and technology in Indonesia. Philosophical heuristics method, which is a step in finding a new way to find the basic framework of scientific existence as a philosophical strategy for problem solving

\section{Results and Discussion}

3.1. The phenomenon of cultural shift in the development of science and technology in Indonesia.

The cultural shift revealed social femomena, namely the shifting of conventional life patterns of the Indonesian people towards the pattern of modern life. In conventional life patterns contained basic values of life that have long been considered noble and gave the character of the nation. Modern life patterns, namely ways of thinking, behaving that are based on practical, pragmatic and positivistic values [3]. In the pattern of modern life, all the criteria for the truth of knowledge and reality of life are measured based on rational values, until the implementation of attitudes and behavior [4]

Modern technology extensively has mastered various fields of life, and is able to intensively change people's ways of thinking (cultural patterns). Changes in the cultural patterns of Indonesian society began to shift to patterns - practical oriented thinking patterns, pragmatic, empiric. This tendency leads to the development of dry life patterns of ethical values, morality, religion and historical values. It seems to be expanding consumptive, materialistic, hedonistic, demoralizing and dehumanizing lifestyles [5] There are various crises in the country, for example, the lower the appreciation of the community for: moral values, the values of love for the homeland, the values of nationalism. Widespread cultural crises can be witnessed in various forms such as disorientation and distortion of values in the lives of Indonesian people. Disorientation is caused by people who increasingly lose basic values that have long been used as life orientations or life grips. People experience shakiness in their view of life, easily swayed and easily affected by provocations that plunge. Distortion as a result of the fragility of the basic values of life, something that is considered noble is now understood to be outdated, while people prefer modern values that are not necessarily in accordance with the cultural values of the Indonesian people. Life becomes bland, arid, and temperamental, easy to carry out various acts of violence and anarchism [6]. The challenge that must be faced by the Indonesian people today is that the trend of scientific development in the 21 st century has freed itself from the theological environment which is metaphysical towards autonomy in a positivistic environment. Science enters quantum evolution that has the potential to uncover new ecological zones and niches for humans. If the process is wrong and its direction, this evolution can end with the extinction of the human species [7]

3.2. Strategies to overcome the problem of cultural shift 3.2.1. Policy Strategy

At present the Indonesian people are entering the 4.0 industrial era, the key word is zero emission. Challenges that must be faced are how to develop electrification, renewable energy, and energy conservation. Indonesia's long-term policy must shift to renewable energy that is more environmentally friendly and has zero emissions. The electricity sector does not generate $\mathrm{CO} 2$, and the important thing is conservation through more efficient energy use. The main objective is for the community to produce only in the amount of carbon dioxide that can be absorbed by nature. This way people will become carbon neutral. Low carbon communities cannot be achieved if people do not change their way of life as they are today [8]. Carbon minimization in all sectors: minimization of carbon dioxide emissions from all sectors. Toword a simpler life style that realize richer quality of life: shifting from mass-consumption society towards QOL oriented society. Revolution led by consumers choice. Coexistence with nature : maintaining and restoring natural environtment that is essential for human society [9]

\subsubsection{Cultural strategy}

We imperatively put our philosophical vision and orientation on Pancasila as a paradigm for the development of science and technology. Pancasila as a paradigm contains several philosophical dimensions, namely the ontological, epistemological and axiological dimensions. The ontological dimension means that the values of Pancasila provide the basis for scientific assumptions and help create interdisciplinary communication. The epistemological dimension, the values of Pancasila are used as a knife of analysis or a method of thinking and a measure of truth. Axiological dimension, means that Pancasila contains imperative values to give direction so that the scientific process 
can find truth, and scientific behavior must be done with honesty. Axiologically, the Pancasila principles are a systemic whole.

The implementation of Pancasila values as a paradigm for the development of science and technology is as follows [10]

- Ketuhanan Yang Maha Esa: (The God head of YME): Complement science creates a balance between rational and irrational, between reason and taste. This precepts puts man in nature as its part and not its center.

- Kemanusiaan yang Adil dan Beradab (A just and civilized humanity): to give direction and to control science. Science is restored to its original function, that is for humanity and not just for certain groups or layers.

- Persatuan Indonesia (The Unity of Indonesia), Implementing science as a means to unite in a pluralistic society pluralism by continuing to develop the values of Indonesian nationalism.

- Kerakyatan yang dipimpin oleh Hikmah Kebijaksanaan dalam Permusyawaratan /Perwakilan (People's precepts, led by the wisdom in the deliberations / representatives), offset the autodynamics of science and technology evolve itself freely. Experimentation of the application and dissemination of science of democracy should be deliberately represented, from policy, research to mass application.

- Keadilan Sosial bagi Seluruh Rakyat Indonesia : (Practice social justice for all Indonesians), emphasizing the three justices of Aristotle: distributive justice, contingative justice, and commutative justice. Social justice also maintains a balance between the interests of individuals and society, because the interests of individuals should not be trampled by false interests. Individuality is the foundation that enables creativity and innovation.

\section{Conclusions}

Changes in the cultural patterns of society in the development of science and technology are inevitable, but these changes should not shift from the basic values of life that have long been a life hold. Philosophical concepts about human beings are needed so that they are not mistaken in placing basic scientific assumptions, development methods and the direction of the development of science and technology. The development of science and technology in Indonesia must be directed to a pattern of development that is oriented towards strengthening the overall framework of scientific existence (ontology, epistemology and axiology). Need public awareness, the importance of understanding that the development of science and technology must reflect a cultural process that can lead to the achievement of essential truths, namely to educate, prosper, and dignity. For this reason, it is necessary for the behavior of the people and scientists who have low carbon culture.

\section{References}

1. Popper, Karl, R., Realism and The Aim of Science, Roman Litlefied, Totowa, New Jersey.79. (1983)

2. Widisuseno, Iriyanto, Peran Filsafat dalam Menyelesaikan Masalah Perkembangan Ilmu Pengetahuan dan Teknologi, UNDIP Press. Semarang, 19,20. (2012)

3. Sutardjo Adisusilo. Problematika Pembangunan Ilmu Pengetahuan, Yayasan Kanisius, Yogyakarta. 67. (1983)

4. Sinaga, Agama-agama di Abad Kontemporer, Jakarta, ix. (2009)

5. Iriyanto Widisuseno, Makalah Seminar: Pancasila dan Kepribadian Bangsa, Undip. (2016)

6. Widisuseno, Iriyanto, Teori Pertumbuhan Pengetahuan Ilmiah Karl R. Popper dan Implementasinya, BP. UNDIP, Semarang.25. (2016)

7. Jacob. T. Manusia, Ilmu dan Teknologi, PT. Tiara Wacana, Yogyakarta. 25,26. (1993)

8. Subroto. Tantangan Revolusi Energi, Suara Merdeka, Semarang, 30/9/. (2018)

9. https://www.env.go.jp/earth/info/pc071211/en.pdf. Building a Low Carbon, Ministry of the Environment, Japan.(2007) 